УДК 616.89-008.441.44-022.343:616.053.71-053.66(571.54):314.114:159.97

Для цитирования: Лубсанова С.В., Петрунько О.В. Суицидальное поведение несовершеннолетних 15-17 лет в Республике Бурятия. Сибирский вестник психиатрии и наркологии. 2020; 1 (106): 67-76. https://doi.org/10.26617/1810-3111-2020-1(106)-67-76

\title{
Суицидальное поведение несовершеннолетних 15-17 лет в Республике Бурятия
}

\section{Лубсанова С.В.' ${ }^{1}$, Петрунько О.В. ${ }^{2}$}

\author{
${ }^{1}$ Бурятский государственный университет им. Доржи Банзарова \\ Россия, 670000, Улан-Удэ, ул. Смолина, $24 a$ \\ ${ }^{2}$ Иркутская государственная медицинская академия последипломного образования- \\ филиал ФГБОУ ДПО РМАНПО Минздрава России \\ Россия,.664049, Иркутск, микрорайон Юбилейный, 100
}

\section{PEЗЮME}

В статье приведены данные о распространенности (на 100 тысяч населения) завершенных самоубийств среди детей и подростков в Республике Бурятия за 2008-2018 гг.; количестве зарегистрированных лиц с незавершенным суицидом среди несовершеннолетних в возрасте 15-17 лет в Республике Бурятия по данным мониторинга Министерства здравоохранения Республики Бурятия в 2014-2018 гг., числе госпитализаций в психиатрический стационар несовершеннолетних в возрасте 15-17 лет по причине совершения суицидальной попытки. Отмечена небольшая доля $(24,1 \%)$ госпитализированных в психиатрический стационар несовершеннолетних 15-17 лет от всех зарегистрированных с незавершенным суицидом в данной возрастной категории. Социально-демографические и клинико-психопатологические характеристики несовершеннолетних парасуицидентов оценивались в двух группах: в группе подростков, впервые обратившихся за специализированной помощью (первичные), и в группе лиц, которые до госпитализации по причине совершения суицидальной попытки получали специализированное амбулаторное или стационарное лечение (повторные). Статистически значимые различия $(\mathrm{p} \leq 0,05)$ среди несовершеннолетних сравниваемых групп были выявлены по следующим позициям: диагноз формирующегося эмоционально неустойчивого расстройства личности по МКБ-10 с преобладанием в группе первичных пациентов и наличие резидуально-органического поражения головного мозга с преобладанием в группе повторных больных. Самым частым видом суицидального поведения у несовершеннолетних парасуицидентов 15-17 лет было нанесение самопорезов, реже зафиксированы самоповешение, отравления лекарственными средствами, в единичных наблюдениях - падения с высоты и суицидальные угрозы. К факторам суицидального риска у несовершеннолетних парасуицидентов 15-17 лет отнесены признаки резидуально-органического поражения головного мозга, суицидальные попытки в анамнезе, асоциальное поведение у членов семьи, девиантное поведение, алкогольное опьянение при суицидальной попытке.

Ключевые слова: суицид, детско-подростковый суицид, парасуицид, подростки, несовершеннолетние, Республика Бурятия.

\section{ВВЕДЕНИЕ}

По данным ВОЗ (2019), около 800000 человек во всем мире ежегодно умирают от самоубийств, практически треть всех самоубийств совершается в молодом возрасте. Суицид является второй по значимости причиной смерти в возрасте 15-29 лет, на каждый завершенный суицид приходится более 20 суицидальных попыток [1]. В последние годы отмечается значительный рост количества суицидов в детском и подростковом возрастах. Россия занимает одно из ведущих мест по суицидам среди контингента несовершеннолетних $[2,3]$.

При наличии пристального внимания к суицидальному поведению несовершеннолетних, проведении большого количества исследова- тельских работ [4-23] особенности суицидальной смертности детей и подростков и причины детско-подросткового суицида остаются не до конца изученной областью знаний в суицидологии с большим количеством вопросов. Сходство микросоциальной ситуации, психофизиологических и социально-демографических характеристик может вызывать, тем не менее, полярные поведенческие реакции у разных подростков, что является непосредственным отражением своеобразия психики в этом возрастном периоде.

Потенциальная суицидальная опасность у данной возрастной категории лиц в том числе связана и с дисгармонически протекающим пролонгированным пубертатным кризом с не- 
стабильностью психоэмоционального фона, недостаточной психологической зрелостью и несформированностью взрослых механизмов контроля над импульсами, высокой чувствительностью к воздействию социальных факторов и выраженной зависимостью психологического состояния от социально-средовых влияний [9].

Остается спорным вопрос о связи психической патологии и суицидального поведения у несовершеннолетних. Высказано предложение не воспринимать всех суицидентов через призму психической патологии и использовать психолого-криминалистический подход при изучении суицидального поведения, в рамках которого основным способом получения информации является проведение посмертной судебно-психиатрической экспертизы [24].

Для построения эффективной профилактики аутодеструктивного поведения у несовершеннолетних требуется комплексный подход с усилением мер первичной профилактики, направленных на предупреждение действия неблагоприятных социальных факторов, способствующих развитию психических заболеваний, а также осуществление мер вторичной профилактики [14]. Необходимо учитывать как ситуационные, так и личностные факторы риска подобного поведения [7]. Следует обратить внимание и на своевременное выявление пресуицидальных состояний у данного контингента лиц для оказания им адекватной социальнопсихологической и психотерапевтической помощи [10]. Своевременное выявление факторов риска позволит сократить случаи аутоагрессивного поведения у юношей допризывного и призывного возрастов [14]. Эффективная профилактика суицидального поведения контингента несовершеннолетних предполагает решение вопросов дестигматизации и повышения уровня социально-психологической адаптации лиц, пытавшихся покончить с собой [16]. В качестве инновационных подходов к предупреждению суицидов и покушений на самоубийство рассматривается снижение потребления алкоголя в популяции [25].

На протяжении ряда лет Республика Бурятия (РБ) наряду с Тывой и Якутией занимает одно из лидирующих мест среди субъектов Российской Федерации с наиболее неблагополучной ситуацией по показателю детско-подростковых суицидов, где частота детского суицида превышает российский уровень в 4-4,5 раза, а подросткового - в 4-6 раз [2].

\section{ЦЕЛЬ ИССЛЕДОВАНИЯ}

Оценить распространенность, социальнодемографические и клинико-психопатологические особенности суицидального поведения несовершеннолетних - пациентов психиатрического стационара в возрасте 15-17 лет в Республике Бурятия.

\section{ЗАДАЧИ ИССЛЕДОВАНИЯ}

Провести анализ динамики распространенности завершенных самоубийств в когорте детей и подростков в Республике Бурятия в 2008-2018 гг. (на 100 тысяч населения), количества незавершенных суицидов среди несовершеннолетних в возрасте 15-17 лет в Республике Бурятия по данным мониторинга Министерства здравоохранения Республики Бурятия в 2014-2018 гг., числа госпитализаций в психиатрический стационар несовершеннолетних в возрасте 15-17 лет по причине совершения суицидальной попытки, оценить социальнодемографические и клинико-психопатологические особенности несовершеннолетних в возрасте от 15 до 17 лет, госпитализированных в ГБУЗ РПНД Республики Бурятия в 2014-2018 гг. с аутодеструктивным (суицидальным) поведением.

\section{МАТЕРИАЛЫ И МЕТОДЫ}

Материалом исследования являлись медицинские карты стационарного больного несовершеннолетних лиц в возрасте от 15 до 17 лет, госпитализированных в ГБУЗ РПНД Республики Бурятия в 2014-2018 гг. с аутодеструктивным (суицидальным) поведением.

Исследование носило сплошной характер. Методом выкопировки данных из истории болезни изучались такие параметры пациентов, как пол, возраст, место проживания, характер суицидальных проявлений, клинические особенности психических расстройств (в том числе наличие проявлений депрессивного синдрома), семейная и социальная ситуация.

Статистическая обработка данных произведена на основе программы «Statistica 10.0 for Windows» (с использованием непараметрического критерия $\chi^{2}$ Пирсона).

\section{РЕЗУЛЬТАТЫ}

Проведен анализ динамики распространенности завершенных самоубийств среди детей и подростков в Республике Бурятия за 2008-2018 гг. (на 100 тысяч населения) (рис. 1).

За рассматриваемый 10-летний период показатель распространенности завершенных самоубийств варьировал от 71,7 в 2008 г. до 12,5 в 2017 г. Несмотря на снижение данного пока- 
зателя с 2008 г. по 2015 г. с 71,7 до 28,6, отмечено существенное его увеличение в 2016 г. до 62,4. В 2018 г. распространенность завершенных суицидов детей и подростков в Республике
Бурятия составила 21,8 на 100 тысяч населения. Таким образом, отмечается неустойчивая, однако в целом положительная динамика по этому показателю.

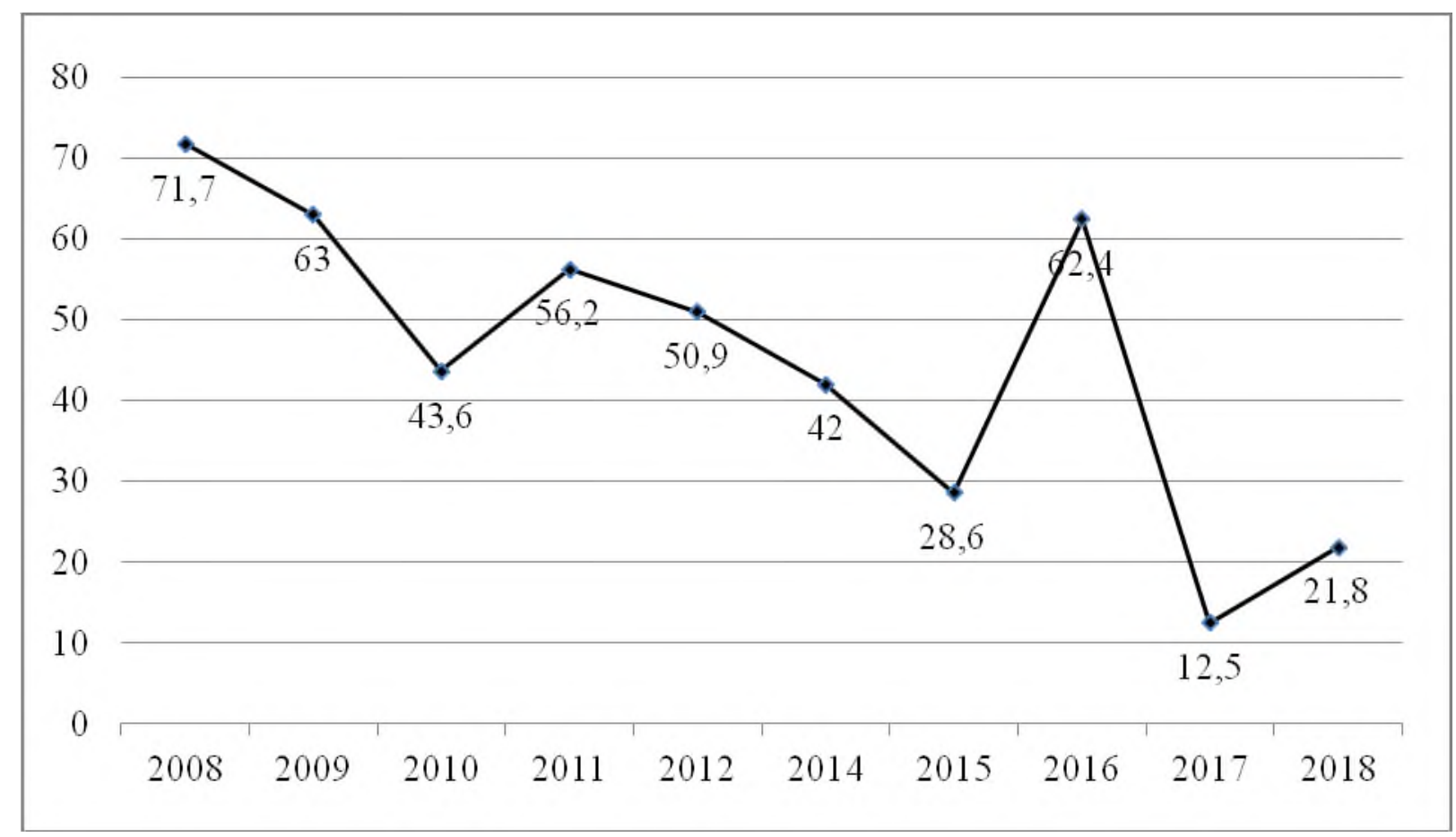

Р и с у н о к 1. Распространенность завершенных суицидов среди детей и подростков в Республике Бурятия в 2008-2018 гг. (на 100 тысяч населения)

Данную тенденцию к снижению отчасти можно связать с активизацией работы учреждений системы здравоохранения в направлении превенции и поственции суицидального поведения, которая была закреплена Приказом № 894-ОД от 25.08.2011 г. Министерства здравоохранения Республики Бурятия «Об оказании специализированной помощи лицам с кризисными состояниями и суицидальным поведением в Республике Бурятия» (изменения в Приказ утверждены 13.03.2017 за № 331-ОД). В соответствии с этим приказом лицу, обратившемуся в медицинское учреждение по причине совершения суицидальной попытки, должна быть предложена и проведена (при получении согласия самого лица или его законного представителя) консультация психиатра.

Показатель завершенных суицидов в категории несовершеннолетних представлен, в основном, подростковым суицидом, что подтверждается устойчивым соотношением завершенных актов у детей до 14 лет и 15-17-летних подростков. Это соотношение в РБ в 2013 г. составляло 3,5 случая у детей и 33 случая у подростков, в 2014 г. -3 и 42, в 2015 г. $-3,2$ и 28,6, в 2016 г. $-3,2$ и 63,6, в 2017 г. $-3,1$ и 12,5 случая соответственно.

В соответствии с данными мониторинга Министерства здравоохранения Республики Бурятия в 2014-2018 гг. осуществлена оценка количества случаев незавершенных суицидов подростков (табл. 1).

\begin{tabular}{|c|c|c|}
\hline \multicolumn{3}{|c|}{$\begin{array}{c}\text { Т а б л и ц а } 1 . \text { Количество несовершеннолетних } \\
\text { парасуицидентов 15-17 лет } \\
\text { в Республике Бурятия в 2014-2018 гг. }\end{array}$} \\
\hline \multirow[t]{2}{*}{ Год } & \multicolumn{2}{|c|}{\begin{tabular}{|c|} 
Количество несовершеннолетних \\
парасуицидентов 15-17 лет \\
\end{tabular}} \\
\hline & $\begin{array}{c}\text { по данным мониторинга } \\
\text { Министерства здраво- } \\
\text { охранения Республики } \\
\text { Бурятия (абс.) }\end{array}$ & $\begin{array}{c}\text { госпитализиро- } \\
\text { ванных в ГБУЗ } \\
\text { РПНД (абс.) }\end{array}$ \\
\hline 2014 & 35 & 6 \\
\hline 2015 & 17 & 5 \\
\hline 2016 & 47 & 8 \\
\hline 2017 & 35 & 8 \\
\hline 2018 & 24 & 11 \\
\hline Всего & 158 & 38 \\
\hline
\end{tabular}

За анализируемый 5-летний период количество зарегистрированных лиц с незавершенным суицидом среди несовершеннолетних в воз- 
расте 15-17 лет составило 158 человек, из них лишь 38 человек $(24,1 \%)$ были госпитализированы в ГБУЗ РПНД. Остальные подростки были госпитализированы в общесоматические больницы $\mathrm{c}$ рекомендациями последующей консультации психиатра. Оценка их медицинских карт является следующим запланированным этапом продолжения исследования с соблюдением этико-деонтологических и юридических аспектов.

Всего госпитализированных в ГБУЗ РПНД парасуицидентов всех возрастов в 2014-2018 гг. было 292 человека, из них старше 18 лет $227(77,7 \%)$, до 18 лет - 65 человек (22,3\%). Среди несовершеннолетних лиц до 14 лет было 27 человек (41,5\%), от 15 до 17 лет - 38 человек $(58,5 \%)$, то есть доля подростков 15-17 лет составила $13,0 \%$ от числа всех госпитализированных парасуицидентов за исследуемый период.

Для анализа социально-демографических и клинико-психопатологических особенностей суицидального поведения выборка $(\mathrm{n}=38)$ госпитализированных в ГБУЗ РПНД несовершеннолетних парасуицидентов 15-17 лет (из них юноши - 15 чел., или $39,5 \%$, девушки - 23 чел., или $60,5 \%$ ) была разделена на две группы: группа 1 (первичные) - лица, впервые обратившиеся за психиатрической помощью после суицидальной попытки (n=19), и группа 2 (повторные) - лица, получавшие до совершения парасуицида специализированное амбулаторное или стационарное лечение по поводу психического расстройства $(\mathrm{n}=19)$.

Социально-демографические характеристики несовершеннолетних парасуицидентов 15-17 лет представлены в таблице 2 .

Т а б л и ц а 2. Социально-демографические характеристики несовершеннолетних парасуицидентов 15-17 лет, госпитализированных в ГБУЗ РПНД

\begin{tabular}{|l|c|c|c|c|}
\hline $\begin{array}{c}\text { Социально- } \\
\text { демографические } \\
\text { характеристики }\end{array}$ & \multicolumn{2}{|c|}{$\begin{array}{c}\text { Группа 1 } \\
\text { (первичные) } \\
\text { (n=19) }\end{array}$} & \multicolumn{2}{c|}{$\begin{array}{c}\text { Группп 2 } \\
\text { (повторные) } \\
\text { (n=19) }\end{array}$} \\
\cline { 2 - 6 } & Абс. & $\%$ & Абс. & $\%$ \\
\hline Юноши & 8 & 42,1 & 7 & 36,8 \\
\hline Девушки & 11 & 57,9 & 12 & 63,2 \\
\hline Городской житель & 9 & 47,4 & 4 & 21,1 \\
\hline Сельский житель & 10 & 52,6 & 15 & 78,9 \\
\hline
\end{tabular}

В обеих группах пациентов преобладали лица женского пола: $57,9 \%$ - в группе 1 (первичные) и $63,2 \%$ - в группе 2 (повторные). Анализ госпитализированных несовершеннолетних по месту проживания показал, что как среди лиц, впервые обратившихся за психиатрической помощью после суицидальной попытки, так и среди пациентов, которые до совершения парасуицида получали специализированное амбулаторное или стационарное лечение по поводу психического расстройства, преобладали сельские жители (52,6\% и 78,9\% соответственно) по сравнению с городскими.

Распределение несовершеннолетних парасуицидентов 15-17 лет по виду суицидального поведения приведено в таблице 3.

Т а б л и ц а 3. Распределение несовершеннолетних парасуицидентов 15-17 лет, госпитализированных в ГБУЗ РПНД по виду суицидального поведения

\begin{tabular}{|l|c|c|c|c|}
\hline $\begin{array}{c}\text { Вид суицидального } \\
\text { поведения }\end{array}$ & \multicolumn{2}{|c|}{$\begin{array}{c}\text { Группа 1 } \\
\text { (первичные) } \\
(\mathrm{n}=19)\end{array}$} & \multicolumn{2}{|c|}{$\begin{array}{c}\text { Группа 2 } \\
\text { (повторные) } \\
(\mathrm{n}=19)\end{array}$} \\
\cline { 2 - 5 } & Абс. & $\%$ & Aбс. & $\%$ \\
\hline Самопорезы & 14 & 73,7 & 12 & 63,2 \\
\hline Самоповешение & 3 & 15,8 & 3 & 15,8 \\
\hline $\begin{array}{l}\text { Отравления лекар- } \\
\text { ственными средствами }\end{array}$ & 0 & 0 & 2 & 10,5 \\
\hline Падения с высоты & 1 & 5,3 & 1 & 5,3 \\
\hline Суицидальные угрозы & 1 & 5,3 & 1 & 5,3 \\
\hline \multicolumn{1}{|c|}{ Всего } & 19 & 100 & 19 & 100 \\
\hline
\end{tabular}

Самым частым видом суицидального поведения в обеих группах было нанесение самопорезов (73,7\% - в группе 1 и $63,2 \%$ - в группе 2$)$, реже регистрировались случаи самоповешения (по 15,8\%), отравления лекарственными средствами (10,5\% в группе 2), в единичных наблюдениях - падения с высоты (по 5,3\%) и суицидальные угрозы (по 5,3\%). Статистических различий по виду суицидального поведения в изученных группах не выявлено.

Нозологическое распределение несовершеннолетних парасуицидентов 15-17 лет в соответствии с МКБ-10 приведено в таблице 4.

Среди несовершеннолетних, впервые обратившихся за психиатрической помощью после суицидальной попытки, преобладали лица с формирующимся эмоционально неустойчивым расстройством личности, пограничный тип (F60.31) - 68,4\%, более чем в 3 раза реже зарегистрированы лица с депрессивным эпизодом тяжелым, без психотических симптомов (F32.2) $-21,1 \%$, в 6,5 раза реже - с органическим аффективным расстройством (F06.3) - 10,5\%. Нозологическая структура повторных пациентов, которые до совершения парасуицида получали специализированное амбулаторное или стационарное лечение по поводу психического расстройства, была более разнообразной: умствен- 
ная отсталость легкая (F70.1) - 31,6\%; органическое аффективное расстройство (F06.3) $26,3 \%$; формирующееся эмоционально неустойчивое расстройство личности, пограничный тип (F60.31) - 21,1\%, шизофрения параноидная (F20.01), эпизодический тип с нарастающим дефектом - 10,5\%; в единичных наблюдениях - расстройство адаптации, смешанное расстройство эмоций и поведения (F43.25) и депрессивный эпизод тяжелый, без психотических симптомов (F32.2) - по 5,25\%. Отмечены статистически значимые различия $\left(\chi^{2}=8,62\right.$, $\mathrm{p} \leq 0,05)$ с достоверным преобладанием формирующегося эмоционально неустойчивого расстройства личности в группе первичных пациентов по сравнению с повторными.

\section{Т а б л и ц а 4. Распределение несовершеннолет- них парасуицидентов 15-17 лет, госпитализиро-} ванных в ГБУЗ РПНД в соответствии с МКБ-10

\begin{tabular}{|c|c|c|c|c|}
\hline \multirow[t]{2}{*}{$\begin{array}{c}\text { Диагноз } \\
\text { по МКБ-10 }\end{array}$} & \multicolumn{2}{|c|}{$\begin{array}{c}\text { Группа 1 } \\
\text { первичные) } \\
(\mathrm{n}=19)\end{array}$} & \multicolumn{2}{|c|}{$\begin{array}{c}\text { Группа } 2 \\
\text { повторные } \\
(\mathrm{n}=19) \\
\end{array}$} \\
\hline & Абс. & $\%$ & Абс. & $\%$ \\
\hline $\begin{array}{l}\text { Органическое аффективное } \\
\text { расстройство (F06.3) }\end{array}$ & 2 & 10,5 & 5 & 26,3 \\
\hline $\begin{array}{l}\text { Шизофрения параноидная } \\
\text { (F20.01) эпизодический тип } \\
\text { с нарастающим дефектом }\end{array}$ & 0 & 0 & 2 & 10,5 \\
\hline $\begin{array}{l}\text { Депрессивный эпизод тяже- } \\
\text { лый без психотических } \\
\text { симптомов (F32.2) }\end{array}$ & 4 & 21,1 & 1 & 5,25 \\
\hline $\begin{array}{l}\text { Расстройство адаптации, } \\
\text { смешанное расстройство } \\
\text { эмоций и поведения (F43.25) }\end{array}$ & 0 & 0 & 1 & 5,25 \\
\hline $\begin{array}{l}\text { Формирующееся эмоцио- } \\
\text { нально неустойчивое рас- } \\
\text { стройство личности, погра- } \\
\text { ничный тип (F60.31) }\end{array}$ & 13 & $68,4 *$ & 4 & $21,1^{*}$ \\
\hline $\begin{array}{l}\text { Умственная отсталость лег- } \\
\text { кая (F70) }\end{array}$ & 0 & 0 & 6 & 31,6 \\
\hline Всего & 19 & 100 & 19 & 100 \\
\hline
\end{tabular}

Пр и м е ч а и и ${ }^{*}-\mathrm{p} \leq 0,05$.

У всех несовершеннолетних парасуицидентов обеих групп (первичных и повторных) на момент госпитализации в психиатрический стационар в структуре психопатологической симптоматики определялось наличие депрессивного синдрома.

Далее в когорте несовершеннолетних пациентов обеих групп был проведен анализ факторов суицидального риска (табл. 5). Учитывались данные о наличии в анамнезе пациентов органического поражения головного мозга различного генеза (перинатальная энцефалопатия, ЧМТ, церебральная гипоксия).
T а б л и ц а 5 . Факторы суицидального риска у несовершеннолетних парасуицидентов 15-17 лет, госпитализированных в ГБУЗ РПНД

\begin{tabular}{|l|c|c|c|c|}
\hline $\begin{array}{c}\text { Фактор суицидального } \\
\text { риска }\end{array}$ & \multicolumn{2}{|c|}{$\begin{array}{c}\text { Группа 1 } \\
\text { (первичные) } \\
(\mathrm{n}=19)\end{array}$} & \multicolumn{2}{|c|}{$\begin{array}{c}\text { Группа } 2 \\
\text { (повторные) } \\
(\mathrm{n}=19)\end{array}$} \\
\cline { 2 - 5 } & Абс. & $\%$ & Абс. & $\%$ \\
\hline $\begin{array}{l}\text { Органическое пораже- } \\
\text { ние головного мозга }\end{array}$ & 10 & $52,6^{*}$ & 19 & $100^{*}$ \\
\hline $\begin{array}{l}\text { Суицидальные попытки } \\
\text { в анамнезе }\end{array}$ & 9 & 47,4 & 8 & 42,1 \\
\hline $\begin{array}{l}\text { Асоциальное поведение } \\
\text { у членов семьи }\end{array}$ & 15 & 78,9 & 14 & 73,7 \\
\hline Девиантное поведение & 13 & 68,4 & 15 & 78,9 \\
\hline $\begin{array}{l}\text { Алкогольное опьянение } \\
\text { при парасуициде }\end{array}$ & 8 & 42,1 & 4 & 21,1 \\
\hline
\end{tabular}

Пр и м е ч а н и е. ${ }^{*}-\mathrm{p} \leq 0,05$.

В группе повторных пациентов признаки резидуально-органического поражения головного мозга регистрировались в $100,0 \%$ случаев по сравнению с первичными пациентами $(52,6 \%)$ со статистически достоверными различиями $\left(\chi^{2}=11,79, p \leq 0,05\right)$. У первичных и повторных пациентов в анамнезе имели место суицидальные попытки ( $47,4 \%$ и $42,1 \%$ соответственно).

При оценке признаков асоциального поведения семьи парасуицидентов учитывались такие факторы, как наличие у родственников первой степени родства зависимости от психоактивных веществ (алкоголя, наркотических средств) и судимости. Признаки асоциального поведения в семье регистрировались у 78,9\% несовершеннолетних группы 1 и 73,7\% подростков группы 2.

Наличие девиантного поведения (злоупотребление алкоголем и наркотическими средствами, курение, бродяжничество, беспорядочная половая жизнь, воровство, употребление ненормативной лексики) у несовершеннолетних парасуицидентов выявлено в $68,4 \%$ случаев в группе 1 и в $78,9 \%$ случаев в группе 2 . В момент совершения парасуицида $42,1 \%$ первичных пациентов и $21,1 \%$ повторных находились в состоянии алкогольного опьянения.

\section{ОБСУЖДЕНИЕ}

Результаты проведенного исследования позволили выделить особенности суицидального поведения - незавершенных суицидальных попыток - у несовершеннолетних 15-17 лет.

Отмечена небольшая доля $(24,1 \%)$ госпитализированных в психиатрический стационар несовершеннолетних 15-17 лет от всех зарегистрированных по данным мониторинга Министерства здравоохранения Республики Бурятия 
несовершеннолетних с незавершенным суицидом. Полученное нами распределение подтверждается результатами зарубежных исследований, в соответствии с которыми в подростковом возрасте лишь 20\% суицидальных попыток приводит к госпитализации в психиатрический стационар [20]. Данная неблагоприятная ситуация обусловлена отказом родителей и самих подростков от госпитализации в психиатрический стационар в связи со стигматизацией, опасениями постановки психиатрического диагноза и попадания под дальнейшее наблюдение психиатра.

Среди изученного контингента парасуицидентов преобладали лица женского пола с соотношением 1,5:1. Данная закономерность также отмечена авторами отечественных и зарубежных исследований $[8,10,12,22,23]$.

Самым частым видом суицидального поведения в обеих группах было нанесение самопорезов $(68,4 \%)$, что совпадает с результатами других исследований $[10,12]$.

Наиболее значимым фактором суицидального риска у подростков является наличие психических и поведенческих расстройств [18, 21]. Так, в наших наблюдениях преобладали лица с формирующимся расстройством личности, органическим аффективным расстройством и депрессивным эпизодом. Суицидальное поведение у всех обследуемых несовершеннолетних возникало на фоне депрессивного синдрома в структуре актуальной психопатологической симптоматики, наличие депрессии при парасуициде отмечено рядом авторов $[4,12,19]$.

Выявлены значимые факторы риска формирования аутоагрессивного поведения подростков - неблагоприятная ситуация в семье [11] и дисфункциональные семьи $[9,12,13,16,19]$, что подтверждено и результатами собственного исследования - асоциальное поведение членов семьи в двух группах совокупно регистрировалось в 76,3\% случаев. Нашел подтверждение и такой фактор суицидального поведения, как наличие в анамнезе пациентов девиантного поведения $[9,10,12,14,17]$ - в 47,4\% случаев в двух группах. В литературе продемонстрирован рост суицидального риска в связи с потреблением алкогольных напитков и психоактивных веществ [9, 12, 14, 16, 25]. Согласно результатам проведенного нами исследования, у $31,6 \%$ несовершеннолетних обеих групп при совершении парасуицида регистрировалось алкогольное опьянение.
Высокая распространенность (76,3\% пациентов двух групп) резидуально-органического поражения головного мозга как фактора риска суицидального поведения подростков продемонстрирована и в других работах $[10,14]$.

В собственном исследовании выборка госпитализированных в ГБУЗ РПНД несовершеннолетних парасуицидентов 15-17 лет для анализа социально-демографических и клиникопсихопатологических особенностей суицидального поведения была разделена на 2 группы: 1) впервые обратившиеся за психиатрической помощью после суицидальной попытки; 2) повторные пациенты, получавшие до совершения парасуицида специализированное амбулаторное или стационарное лечение по поводу психического расстройства. Статистически значимые различия $(\mathrm{p} \leq 0,05)$ среди пациентов обеих групп выявлены лишь по двум позициям: диагноз формирующегося эмоционально неустойчивого расстройства личности по МКБ-10 с преобладанием в группе первичных больных и наличие органического поражения головного мозга с преобладанием в группе повторных. Это свидетельствует об общности подходов к превенции суицидального поведения как среди получающих психиатрическую помощь, так и среди не обращающихся ранее к психиатру.

\section{ВЫВОДЫ}

Показатель распространенности завершенных самоубийств среди детей и подростков в Республике Бурятия за 2008-2018 гг. (на 100 тысяч населения) варьировал от 71,7 в 2008 г. до 12,5 в 2017 г.

Количество зарегистрированных лиц с незавершенным суицидом среди несовершеннолетних 15-17 лет в Республике Бурятия по данным мониторинга Министерства здравоохранения Республики Бурятия в 2014-2018 гг. составило 158 человек, из них лишь 24,1\% были госпитализированы в психиатрический стационар.

Нозологическая структура психических расстройств у несовершеннолетних парасуицидентов 15-17 лет представлена органическим аффективным расстройством (F06.3), шизофренией параноидной (F20.01) с эпизодическим типом и нарастающим дефектом, депрессивным эпизодом тяжелым без психотических симптомов (F32.2), расстройством адаптации со смешанным расстройством эмоций и поведения (F43.25), формирующимся эмоционально неустойчивым расстройством личности пограничного типа (F60.31), умственной отсталостью легкой (F70). 
У всех несовершеннолетних парасуицидентов 15-17 лет на момент госпитализации в психиатрический стационар в структуре психопатологической симптоматики определялось наличие депрессивного синдрома.

Самый частый вид суицидального поведения у несовершеннолетних парасуицидентов 15-17 лет - нанесение самопорезов, реже встречались самоповешение и отравления лекарственными средствами, в единичных наблюдениях - падения с высоты и суицидальные угрозы.

К факторам суицидального риска у несовершеннолетних парасуицидентов $15-17$ лет отнесены признаки резидуально-органического поражения головного мозга, суицидальные попытки в анамнезе, асоциальное поведение членов семьи, девиантное поведение, алкогольное опьянение при суицидальной попытке.

\section{ЗАКЛЮЧЕНИЕ}

Проведенное исследование социальнодемографических и клинико-психопатологических особенностей суицидального поведения у несовершеннолетних в Республике Бурятия позволяет выявить группы риска по суицидальной готовности для проведения профилактических мероприятий. Особого внимания для профилактики суицидального поведения требует ранний юношеский возраст (14-17 лет), который является высокосуицидопасным в связи с повышенной конфликтностью со средой, которая способствует формированию агрессивности, ригидности, тревожности и фрустрированности, что воспринимается как неприспособленность к окружающей среде, ведет к раннему употреблению алкоголя и наркотиков. Данный возрастной период характеризуется и физиологическими факторами риска суицидального поведения: повышенный уровень экскреции катехоламинов, изменчивый катехоламиновый индекс, повышенное содержание всех категорий липопероксидов [15].

Для Республики Бурятия актуальным при разработке мероприятий, направленных на профилактику суицидального поведения у детей и подростков, является учет социальноэкономической ситуации в регионе и этнокультуральных особенностей $[3,5,6]$, создание отвечающей современным научным требованиям системы суицидологической помощи детям и подросткам. Одним из важных направлений является решение вопроса о дестигматизации в аспекте своевременного оказания психологопсихиатрической помощи, который может быть реализован путем включения консультативной психиатрической помощи в условиях педиатрической и общесоматической сети. Крайне необходимыми направлениями являются разработка и внедрение экспедиционного метода в работу суицидологических служб по профилактике самоубийств среди несовершеннолетних, проживающих в отдаленных и труднодоступных сельских районах Республики Бурятия; разработка программ обучения врачейпедиатров, педагогов, психологов и других специалистов, профессионально работающих с детьми и подростками, навыкам раннего распознавания проявлений суицидального поведения и проведения профилактических мероприятий.

\section{КОНФЛИКТ ИНТЕРЕСОВ}

Авторы заявляют об отсутствии явных и потенциальных конфликтов интересов в связи с публикацией данной статьи.

\section{ИСТОЧНИК ФИНАНСИРОВАНИЯ}

Статья подготовлена при финансовой поддержке РФФИ в рамках проекта № 18-01300620 А «Междисциплинарное исследование причин и региональных факторов суицидального поведения несовершеннолетних».

\section{СООТВЕТСТВИЕ ПРИНЦИПАМ ЭТИКИ}

Исследование проведено с соблюдением норм современной биомедицинской этики и этических стандартов, разработанных в соответствии с Хельсинской декларацией ВМА (протокол заседания Комитета по этике ФГБОУ ВО «Бурятский государственный университет им. Доржи Банзарова» № 2 от 04.12.2016 г.).

\section{ЛИТЕРАТУРА}

1. Самоубийство. Всемирная организация здравоохранения [Электронный ресурс]. URL: http:///www.who.int/ru/news-room/fact-sheets/detail/suicide

2. Панченко Е.А., Положий Б.С. Суицидальная ситуация среди детей и подростков в России. Российский психиатрический журнал. 2012; 1: 52-56.

3. Положий Б.С., Фритлинский В.С., Агеев С.Е. Частота суицидов среди несовершеннолетних в России. Российский психиатрический журнал. 2016; 5: 52-54.

4. Бабарахимова С.Б. Клинические проявления суицидального поведения в подростковом возрасте. Личность в меняющемся мире: здоровье, адаптация, развитие. 2017; 1 (16): 62-71.

5. Дашиева Б.А. Этнокультуральные особенности суицидального поведения у подростков с ограниченными возможностями здоровья бурятской и русской национальности. Сибирский вестник психиатрии и наркологии. 2013; 6 (81): 64-67.

6. Ворсина О.П. Суицидальные попытки детей и подростков в г. Иркутске. Суищидология. 2011; 2: 28-29.

7. Евсеенкова Е.В. Факторы риска аутодеструктивного поведения у старших подростков. Вестник Кемеров- 
ского государственного университета. 2019; 1 (77): 74-86. DOI: 10.21603/2078-8975-2019-21-1-74-86

8. Злова Т.П., Ишимбаева А.Н., Ахметова И.И. Социально-психологические особенности незавершенных суицидов у детей и подростков (Забайкальский край, г. Чита). Суицицология. 2011; 2: 26-28.

9. Кравченко Н.Е., Зикеев С.А. Особенности психической патологии и поведения у подростков мужского пола, экстренно госпитализированных в связи с суицидальными действиями. Современная терапия в психиатрии и неврологии. 2014; 3: 20-23.

10. Кривулин Е.Н., Кривулина О.Е. Социальнодемографическая и клинико-психологическая характеристика лиц детско-подросткового возраста с завершенными суицидами и суицидальным поведением. Тюменский медицинский журнал. 2014; 1: 6-8.

11. Кувшинова Т.И., Овчинникова И.П. Современные тенденции суицидального поведения детей и подростков-сирот. Суицидология. 2011; 3: 41-43.

12. Мазаева Н.А., Кравченко С.А., Зикеев Н.Е. Незавершенные суицидальные попытки у подростков. Журнал неврологии и психиатрии им. С.С. Корсакова. Спецвыпуск. 2016; 116(4): 44-49.

13. Минуллина А.Ф., Сарбаева О.Ю. Взаимосвязь факторов семейного воспитания и суицидальной активности подростков. Практическая медищина. 2015; 5: 27-30.

14. Мыльникова Ю.А., Наджарьян С.С. Клинические и социальные предикторы аутоагрессивного поведения лиц допризывного и призывного возраста. Тюменский медииинский журнал. 2014; 16-17.

15. Романова И.В. Психофизиологические критерии риска суицидального поведения у школьников 14-17 лет: автореф. дис. ... канд. биол. наук. Челябинск, 2010: 22.

16. Руженкова В.В., Руженков В.А. Суицидальное поведение в подростковом и юношеском возрасте. Научные ведомости Белгородского государственного университета. Серия: Медицина. Фармация. 2011; 16 (11): 26-32.

17. Саркиапоне М., Положий Б.С. Суициды у детей и подростков. Российский психиатрический журнал. 2014; 3: 52-56.

18. Bella M.E., Fernandez R.A., Willington J.M. Depression and the conduct disorder are the most frequent pa- thologies in child and adolescent suicide attempt. Arch Argent Pediatrics. 2010; 108(2): 124-129. doi: 10.1590/S0325-00752010000200006

19. Hetrick S.E., Parker A.G., Robinson J., Hall N., Vance A. Predicting suicidal risk in a cohort of depressed children and adolescents. Crisis. 2012; 33 (1): 13-20. doi: 10.1027/0227-5910/a000095

20. Mars B., Heron J., Crane C., Hawton K., Lewis G., Macleod J., Tilling K., Gunnell D. Clinical and social outcomes of adolescent self-harm: population based birth cohort study. BMJ. 2014; 349: 5954. doi: 10.1136/bmj.g5954

21. Rhodes A.E., Boyle M.H., Bridge J.A., Sinyor M., Links P.S., Tonmyr L., Skinner R., Bethell J.M., Carlisle C., Goodday S., Hottes T.S., Newton A., Bennett K., Sundar P., Cheung A.H., Szatmari P. Antecedents and sex/gender differences in youth suicidal behavior. World J Psychiatry. 2014; 4(4): 120-132. doi: 10.5498/wjp.v4.i4.120

22. Silva R.S.J., dos Santos F.L.R., Soares N.M.M., Pardono E. Suicidal ideation and associated factors among adolescents in northeastern Brazil. Scientific World Journal. 2014; 2014:450943. doi: $10.1155 / 2014 / 450943$

23. Strandheim A., Bjerkeset O., Gunnel D., Bjørnelv S., Holmen T.L., Bentzen N. Risk factors for suicidal thoughts in adolescence - a prospective cohort study: the Young-Hunt study. BMJ Open. 2014; 4: 005867. doi: 10.1136/bmjopen-2014-005867

24. Епанчинцева Г.А., Волосова Н.Ю., Козловская Т.Н. Самоубийство: законодательные, психологические и криминологические аспекты. Криминологический журнал Байкальского государственного университета экономики и права. 2015; 2: 234-247.

25. Сахаров А.В., Говорин Н.В. Суицидальное поведение и потребление алкоголя: оценка взаимосвязей на популяционном уровне. Суицидология. 2015; 2 (19): 35-46.

Поступила в редакцию 1.11.2019 Утверждена к печати 27.01.2020

Лубсанова Светлана Викторовна - кандидат медицинских наук, доцент медицинского факультета. SPIN-код 9294-3313. Author ID 656023.

Петрунько Ольга Вячеславна - кандидат медицинских наук, доцент, заведующая кафедрой психиатрии и наркологии. SPIN-код 2041-5505. Author ID: 407791.

Лубсанова Светлана Викторовна, 1sv1972@mail.ru

Петрунько Ольга Вячеславна, petrounko@mail.ru 
For citation: Lubsanova S.V., Petrunko O.V. Suicidal behavior of minors aged 15-17 years in the Republic of Buryatia. Siberian Herald of Psychiatry and Addiction Psychiatry. 2020; 1 (106): 67-76. https://doi.org/10.26617/18103111-2020-1(106)-67-76

\title{
Suicidal behavior of minors aged 15-17 years in the Republic of Buryatia
}

\section{Lubsanova S.V.', Petrunko O.V. ${ }^{2}$}

\author{
${ }^{1}$ Buryat State University named after Dorzhi Banzarov \\ Smolin Street 24a, 670000, Ulan-Ude, Russian Federation \\ ${ }^{2}$ Irkutsk State Medical Academy of Postgraduate Education \\ Yubileiny Catchment Area 100, 664049, Irkutsk, Russian Federation
}

\begin{abstract}
The paper presents data on the prevalence (per 100 thousand people) of completed suicides among children and adolescents in the Republic of Buryatia for 2008-2018; the number of registered persons with incomplete suicide among minors aged 15-17 years in the Republic of Buryatia according to monitoring of the Ministry of Health of the Republic of Buryatia in 2014-2018, the number of hospitalizations in the psychiatric hospital for minors aged 15-17 years; the cause for the suicide attempt. A small proportion (24.1\%) of minors 15-17 years old who are admitted to a psychiatric hospital of all those registered with incomplete suicide in this age category is noted. Socio-demographic and clinical-psychopathological characteristics of juvenile parasuicides are evaluated in two groups: in the group of adolescents with the first request for specialist care (primary), and in the group of people who have received specialist outpatient care before hospitalization due to a suicidal attempt or inpatient treatment (repeated). Statistically significant differences $(\mathrm{p} \leq 0.05)$ among the juvenile compared groups are identified on the following positions: the diagnosis of the emotionally unstable personality disorder according to ICD-10 with the predominance in the group of primary patients and the presence of residual-organic brain damage with the predominance in the group of repeated patients. The most common form of suicidal behavior in juvenile parasuicides of 1517 years old is self-cutting, self-hanging, drug poisoning is less often recorded, in single observations - falls from the height and suicidal threats. The factors of suicide risk in juvenile parasuicides aged 15-17 years include signs of residual organic brain damage, suicidal attempts in the anamnesis, asocial behavior of the family, deviant behavior, alcohol intoxication during the suicidal attempt.
\end{abstract}

\section{Keywords: suicide, teenage suicide, parasuicide, adolescents, minors, Republic of Buryatia.}

\section{REFERENCES}

1. Samoubiistvo [Suicide]. World Health Organization [Elektronnyi resurs]. URL: http:///www.who.int/ru/newsroom/fact-sheets/detail/suicide (in Russian).

2. Panchenko E.A., Polozhy B.S. Suitsidal'naya situatsiya sredi detei i podrostkov v Rossii [Suicide situation in Russia among children and teenagers]. Rossiiskii psikhiatricheskii zhurnal - Russian Journal of Psychiatry. 2012; 1: 52-56 (in Russian).

3. Polozhy B.S., Fritlinsky V.S., Ageev S.E. Chastota suitsidov sredi nesovershennoletnikh $\mathrm{v}$ Rossii [The rate of suicide among minors in Russia]. Rossiiskii psikhiatricheskii zhurnal - Russian Journal of Psychiatry. 2016; 5: 52-54 (in Russian).

4. Babarakhimova S.B. Klinicheskie proyavleniya suitsidal'nogo povedeniya $\mathrm{v}$ podrostkovom vozraste [Clinical manifestations of suicidal behavior in puberty period]. Lichnost'v menyayushchemsya mire: zdorov'e, adaptatsiya, razvitie - Personality in a Changing World: Health, Adaptation, Development. 2017; 1 (16): 62-71 (in Russian).

5. Dashieva B.A. Etnokul'tural'nyye osobennosti suitsidal'nogo povedeniya u podrostkov s ogranichennymi vozmozhnostyami zdorov'ya buryatskoy i russkoy natsional'nosti [Ethnocultural features of suicidal behavior in adolescents with limited health capabili- ties of Buryat and Russian nationalities]. Sibirskiy vestnik psikhiatrii $i$ narkologii - Siberian Herald of Psychiatry and Addiction Psychiatry. 2013; 6 (81): 64-67 (in Russian).

6. Vorsina O.P. Suitsidal'nyye popytki detey i podrostkov v gorode Irkutske [Suicidal attempts by children and adolescents in the city of Irkutsk]. Suitsidologiya - Suicidology. 2011; 2: 28-29 (in Russian).

7. Evseenkova E.V. Faktory riska autodestruktivnogo povedeniya u starshikh podrostkov [The risk factors of auto-destructive behavior in adolescents]. Vestnik Kemerovskogo gosudarstvennogo universiteta - Bulletin of Kemerovo State University. 2019; 1 (77): 74-86. DOI: $10.21603 / 2078-8975-2019-21-1-74-86$ (in Russian).

8. Zlova T.P., Ishimbaeva A.N., Akhmetova I.I. Sotsial'no-psikhologicheskie osobennosti nezavershennykh suitsidov u detei i podrostkov (Zabaikal'skii krai, g. Chita) [Social-psychological features of incomplete suicides in children and adolescents (Transbaikalian Krai, Chita)]. Suitsidologiya - Suicidology. 2011; 2: 26-28 (in Russian).

9. Kravchenko N.E., Zikeev S.A. Osobennosti psikhicheskoi patologii i povedeniya u podrostkov muzhskogo pola, ekstrenno gospitalizirovannykh v svyazi s suitsidal'nymi deistviyami [Features of mental pathol- 
ogy and behavior in male adolescents urgently hospitalized due to suicidal action]. Sovremennaya terapiya $v$ psikhiatrii i nevrologii - Modern Therapy in Psychiatry and Neurology. 2014; 3: 20-23 (in Russian).

10. Krivulin E.N., Krivulina O.E. Sotsial'nodemograficheskaya i kliniko-psikhologicheskaya kharakteristika lits detsko-podrostkovogo vozrasta s zavershennymi suitsidami i suitsidal'nym povedeniem [Socio-demographic and clinicalpsychological characteristics of children and adolescents with completed suicides and suicidal behavior]. Tyumenskii meditsinskii zhurnal - Tyumen Medical Journal. 2014; 1: 6-8 (in Russian).

11. Kuvshinova T.I., Ovchinnikova I.P. Sovremennye tendentsii suitsidal'nogo povedeniya detei i podrostkov-sirot [Modern tendencies of suicidal behavior of child and adolescent orphans]. Suitsidologiya Suicidology. 2011; 3: 41-43 (in Russian).

12. Mazaeva N.A., Kravchenko S.A., Zikeev N.E. Nezavershennye suitsidal'nye popytki u podrostkov [Uncompleted suicide attempts in adolescents]. Special Issue. Zhurnal nevrologii $i$ psikhiatrii im. S.S. Korsakova. Spetsvypusk - S.S. Korsakov Journal of Neurology and Psychiatry. 2016; 116(4): 44-49 (in Russian).

13. Minullina A.F., Sarbaeva O.Yu. Vzaimosvyaz' faktorov semeinogo vospitaniya i suitsidal'noi aktivnosti podrostkov [Correlation between factors of family education and suicidal activity of teenagers]. Prakticheskaya meditsina - Practical Medicine. 2015; 5: 27-30 (in Russian).

14. Mylnikova Yu.A., Nadzharyan S.S. Klinicheskie i sotsial'nye prediktory autoagressivnogo povedeniya lits doprizyvnogo i prizyvnogo vozrasta [Clinical and social predictors of auto-aggressive behavior of persons of pre-draft and draft age]. Tyumenskii meditsinskii zhurnal - Tyumen Medical Journal. 2014; 16-17 (in Russian).

15. Romanova I.V. Psikhofiziologicheskie kriterii riska suitsidal'nogo povedeniya u shkol'nikov 14-17 let [Psychophysiological risk criteria for suicidal behavior in students aged 14-17 years]: abstract of the dissertation of the candidate of biological sciences. Chelyabinsk, 2010: 22 (in Russian).

16. Ruzhenkova V.V., Ruzhenkov V.A. Suitsidal'noe povedenie $\mathrm{v}$ podrostkovom i yunosheskom vozraste [Suicidal behaviour in adolescence and youth]. Nauchnye vedomosti Belgorodskogo gosudarstvennogo universiteta. Seriya: Meditsina. Farmatsiya Scientific reports of Belgorod State University. Series: Medicine. Pharmacy. 2011; 16 (11): 26-32 (in Russian).
17. Sarkiapone M., Polozhy B.S. Suitsidy u detei i podrostkov [Suicides in children and teenagers]. Rossiiskii psikhiatricheskii zhurnal - Russian Journal of Psychiatry. 2014; 3: 52-56 (in Russian).

18. Bella M.E., Fernandez R.A., Willington J.M. Depression and the conduct disorder are the most frequent pathologies in child and adolescent suicide attempt. Arch Argent Pediatrics. 2010; 108(2): 124-129. doi: 10.1590/S0325-00752010000200006

19. Hetrick S.E., Parker A.G., Robinson J., Hall N., Vance A. Predicting suicidal risk in a cohort of depressed children and adolescents. Crisis. 2012; 33 (1): 13-20. doi: 10.1027/0227-5910/a000095

20. Mars B., Heron J., Crane C., Hawton K., Lewis G., Macleod J., Tilling K., Gunnell D. Clinical and social outcomes of adolescent self-harm: population based birth cohort study. BMJ. 2014; 349: 5954. doi: 10.1136/bmj.g5954

21. Rhodes A.E., Boyle M.H., Bridge J.A., Sinyor M., Links P.S., Tonmyr L., Skinner R., Bethell J.M., Carlisle C., Goodday S., Hottes T.S., Newton A., Bennett K., Sundar P., Cheung A.H., Szatmari P. Antecedents and sex/gender differences in youth suicidal behavior. World J Psychiatry. 2014; 4(4): 120-132. doi: 10.5498/wjp.v4.i4.120

22. Silva R.S.J., dos Santos F.L.R., Soares N.M.M., Pardono E. Suicidal ideation and associated factors among adolescents in northeastern Brazil. Scientific World Journal. 2014; 2014:450943. doi: $10.1155 / 2014 / 450943$

23. Strandheim A., Bjerkeset O., Gunnel D., Bjørnelv S., Holmen T.L., Bentzen N. Risk factors for suicidal thoughts in adolescence - a prospective cohort study: the Young-Hunt study. BMJ Open. 2014; 4: 005867. doi: 10.1136/bmjopen-2014-005867

24. Epanchintseva G.A., Volosova N.Yu., Kozlovskaya T.N. Samoubiistvo: zakonodatel'nye, psikhologicheskie i kriminologicheskie aspekty [Suicide: legislative, psychological and criminological aspects]. Kriminologicheskii zhurnal Baikal'skogo gosudarstvennogo universiteta ekonomiki i prava - Criminological Journal of the Baikal State University of Economics and Law. 2015; 2: 234-247 (in Russian).

25. Sakharov A.V., Govorin N.V. Suitsidal'noe povedenie i potreblenie alkogolya: otsenka vzaimosvyazei na populyatsionnom urovne [Suicidal behavior and alcohol: estimation of correlations at the population level]. Suitsidologiya - Suicidology. 2015; 2 (19): 35-46 (in Russian).

Received November 1.2019 Accepted January 27.2020

Lubsanova Svetlana V. - PhD, associate professor, Buryat State University named after Dorzhi Banzarov, Ulan-Ude, Russian Federation. SPIN-code 9294-3313. Author ID 656023.

Petrunko Olga V. - PhD, associate professor, Head of the Department of Psychiatry and Narcology, Irkutsk State Medical Academy of Postgraduate Education, Irkutsk, Russian Federation. SPIN-code 2041-5505. Author ID 407791.

Lubsanova Svetlana V., 1sv1972@mail.ru

Petrunko Olga V., petrounko@mail.ru 